\title{
THE RESIDUAL TOXICITY OF ACTARA AND DECIRIN INSECTICIDES TO ADULTS OF STINK BUG Apodiphus amygdali (Germar) (HEMIPTERA: PENTATOMIDAE)
}

Riyadh Ahmed Al-Iraqi * Sarkawt Hussein Muhammed**

*Biology Department, College of Science, College of Science-University of Mosul, Iraq

**Biology Department, College of Science, University of Salahaddin-Erbil, Iraq

\begin{abstract}
The present work was undertaken to study the residual toxicity of the two insecticides Actara and Decirin against adult stink bug A. amygdali. The results showed that the type of insecticide, rate of application used and period after spraying of treated trees, all factors influenced the mortality of the adult $A$. amygdali. Actara gave $37.03 \%$ and $80.00 \%$ mortality at 0.1 and $2.5 \mathrm{mg} / \mathrm{gal}$. application rates, respectively for 1 day. Decirin gave $33.33 \%$ mortality for 1 day at rate of $0.1 \mathrm{ml} / \mathrm{gal}$. water, and rise to $83.33 \%$ when application rate rise to 2.5 $\mathrm{ml} / \mathrm{gal}$.
\end{abstract}

\section{INTRODUCTION}

The fruit trees stink bug $A$. amygdali is one of the pentatomid plant feeding stink bugs, which attacks many of the fruit trees especially plum, apricot, apple, olive, and pear. Furthermore non-fruit trees viz. poplar, pine, planetree, willow bark may also be infested (Muhammed, 1994). Both nymphs and adults feed by sucking plant sap. They are believed to inject toxic substance into the plant when feeding to break down plant tissues (PennState, 2006). It's also noted that sucking juice from the stems, leaves and immature fruits giving rise to host weakness then encouraging to attacks by other insects. Severe infestation leads to fruit degradation (Schuh and Slater, 1995).

The stink bug population in past was controlled with chemicals including, lindane, DDT, dieldrin and parathion (Borden et al., 1952). After that, Thiodan (endosulfan), Cygon 267 (dimethoate), and Carzol SP (formetanate hydrochloride) were reported as possible stink bug controls (Anonymous, 1978).

Khattak et al. (2004), evaluate the efficacy of Mospilan 20SP, Actara 25WG, polo 500EC, Tamaron 60SI and confidor 200SL against sucking plant juice insects, whitefly, jassids, and thrips on mungbean. All the tested insecticides reduced the mean percent population of whiteflies even at 240 hours after spray. Hopkins (2005) founded that mortality of Euschistus servus (Say) was greater than that of $N$. viridula (L.) when exposed to thiamethoxam alone. Deltamethrin is a synthetic insecticide based structurally on natural pyrethrins, which kills insect on contact and through digestion and rapidly paralyzes the insect nervous system giving a quick knockdown effect (Nica et al., 2004).

Reviewing the literature, the informations available about $A$. amygdali in Iraq and other parts of the world considered as records of this insect on the hosts. The goal of the study is to evaluate the residual toxicity of Actara and Decirin against adult of $A$. amygdali in the field

Part of Ph.D. thesis for the second researcher 2009

Received date 21/7/2010 accepted 4/10/2010 


\section{MATERIALS AND METHODS}

1- Insecticides used: Residual toxicity of the two kinds of insecticides were used against adult of $A$. amygdali, these insecticides are:

1- Actara 25 WG, (From Syngenta company), the active ingredient is thiamethoxam (second-generation neonicotinoids) class of compounds that have both contact and systemic activity against a variety of pests such as aphids, whiteflies, thrips, stink bugs on vegetables, pome fruits, pears and on companion animals (NAR, 2001). It interferes with the nicotinic acetylcholine receptors in the nervous system of the insect (Maienfisch et al., 2001). Actara having broad activity against pests and claimed to have minimal impact on beneficial (predator) insects (Antunes-Kenyon and Kennedy, 2001) used at rates of 1.0, 1.5 and 2 gm/gallon water.

2- Decirin 25 EC (From Chemvet company) belongs to pyrothroid group; the active ingredient is Deltamethrin $25 \mathrm{gm} \mathrm{w} / \mathrm{v}$ with contact and stomach action. It is broad spectrum insecticide against detrimental insects belonging to several orders, used at rates of 1.0, 1.5 and $2 \mathrm{ml} /$ gallon water.

The insecticides used in the experiment were obtained from the local market.

2- Treatment: The application of each insecticidal treatment was applied in the field at August 2008 by using a low volume type sprayer. For this purpose many pear trees were selected from the orchard of Erbil city center. After 1 hour spraying, 10 individuals of $A$. amygdali were placed on the treated branches within cage of ( $1 \mathrm{~m} \times 1 \mathrm{~m})$ made from muslin tied to the branch of the treated trees. Adults of $A$. amygdali used for tested were collected from many fruit and non-fruit trees found in the same situation.

Five replicates were used for each treatment and the mortality counts were recorded after 1, 2, 3, 4 and 5 days after insect exposure to the treated trees. Control mortalities were corrected for by Abbott's formula (Abbott, 1925). Calculated of dosage mortality curves and the estimation of $\mathrm{LC}_{90}$ value based on the corrected data were carried out using the standard probit method (Finney, 1971).

\section{RESULTS AND DISCUSSION}

Data concerning the residual toxicity of Actara and Decirin sprayed on the pear trees in the field in August 2008 to the adult A. amygdali are shown in table (1) and graphically illustrated in figure (1).

The results showed that the type of insecticide, rate of application used and period after spraying of treated trees all these factors influenced the mortality of the adult $A$. amygdali. The mortality increased with the increasing rates of insecticide used. Actara insecticide gave 37.03 and $80.01 \%$ mortality at 0.1 and $2.5 \mathrm{mg} / \mathrm{gal}$. application rates respectively, for 1 day of adult exposure to the treated trees. Decirin gave $33.33 \%$ mortality for 1 day of adult exposure to the trees sprayed with the insecticide at rate of $0.1 \mathrm{ml} / \mathrm{gal}$. water, whereas the mortality rised to $83.33 \%$ when rising the application rate to $2.5 \mathrm{ml} / \mathrm{gal}$.

On the other hand, the increase in exposure period of adults to the treated trees increased the mortality percentage. The exposure of adults to pear trees treated with Decirin at rate of $2.5 \mathrm{ml} /$ gal. water for 1 day after spraying gave $83.33 \%$ mortality where the mortality rised to reach $100 \%$ after 3 days of exposure period. So Actara 
insecticide at the same rate of application gave $80.00 \%$ mortality to adult for 1 day after exposure to its deposits on sprayed trees while gave 100\% mortality after 4 days.

Based on the $\mathrm{Lc}_{90}$ values, results revealed that Decirin insecticide proved to be more effective than Actara. Decirin gave an $\mathrm{Lc}_{90}$ values of 3.0 and $2.0 \mathrm{ml} / \mathrm{gal}$ after 1 and 2 days exposure period after spraying respectively, while Actara gave $\mathrm{Lc}_{90}$ values of 3.45 and $3.2 \mathrm{gm} / \mathrm{gal}$ at the same periods respectively.

Results obtained based on $\mathrm{Lc}_{90}$ values indicated that the effect of Decirin insecticidal deposites was 1.15 and 1.6 times more than Actara at 1 and 2 days adult exposure to the insecticidal deposits.

Table (1): Residual toxicity of Actara and Decirin insecticides to the adults of $A$. amygdali

\begin{tabular}{|c|c|c|c|c|c|c|}
\hline & & \multicolumn{5}{|c|}{$\%$ morality at different interval after } \\
Insecticides & Rate of application & \multicolumn{5}{|c|}{ spray (in days) } \\
\hline Used & Gm or ml/gallon & 1 & 2 & 3 & 4 & 5 \\
\hline Actara & 0.1 & 37.03 & 62.96 & 70.83 & 71.42 & 85.71 \\
\hline & 1.5 & 51.35 & 74.07 & 83.33 & 90.48 & 95.24 \\
\hline & 2 & 73.34 & 80.00 & 86.68 & 100.00 & 100.00 \\
\hline & 2.5 & 80.01 & 85.71 & 91.66 & 100.00 & 100.00 \\
\hline Decirin & 0.1 & 33.33 & 63.33 & 87.50 & 100.00 & 100.00 \\
\hline & 1.5 & 53.33 & 73.33 & 100.00 & 100.00 & 100.00 \\
\hline & 2 & 70.00 & 90.00 & 100.00 & 100.00 & 100.00 \\
\hline & 2.5 & 83.33 & 95.24 & 100.00 & 100.00 & 100.00 \\
\hline Actara & $\mathrm{Lc}_{90}$ & 3.45 & 3.2 & & & \\
\hline Decirin & $\mathrm{Lc}_{90}$ & 3.0 & 2.0 & & & \\
\hline
\end{tabular}

Apodiphus amygdali التاثير السمي لكل من مبيدي Actara و لى كاملات البق النتن (recirin (Germar) (Hemiptera: Pentatomidae)

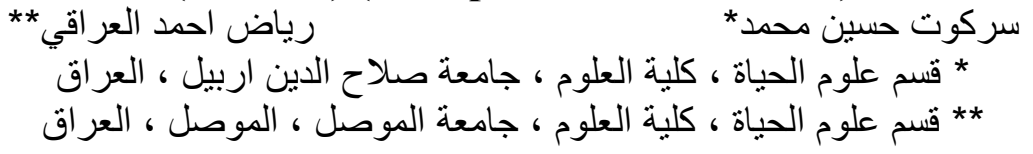

الخلاصة

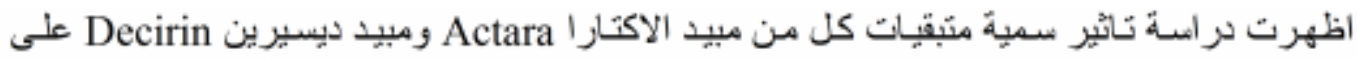

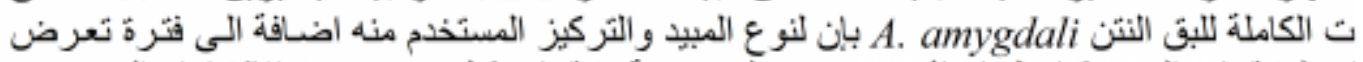

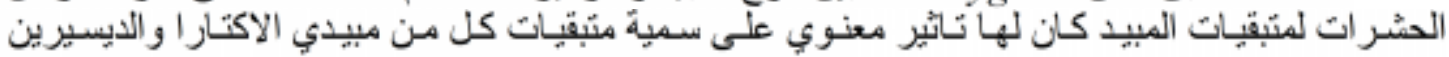

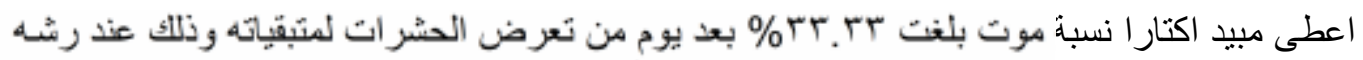

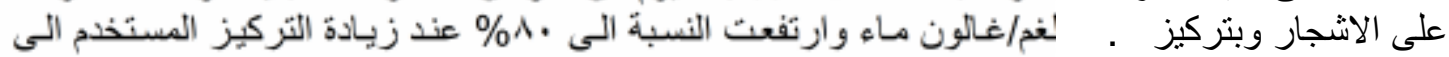

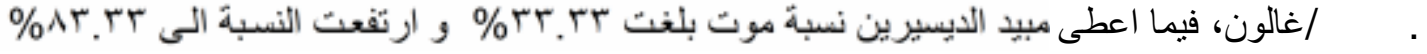

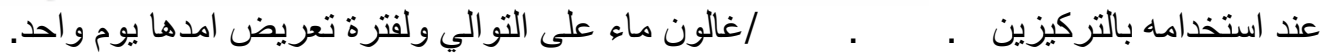

\section{REFERENCES}


Abbott, A. K. (1925). A method of computing the effectiveness of an insecticide. J. Econ. Ent., 18:265-267.

Anonymous (1978). Pear Pest Management. University of California, Division of Agriculture Science. Richmond, CA. 234 p.

Antunes-Kenyon, S. E. and G. Kennedy (2001). Thiamethoxam, a new active ingredient review, for the Massachusetts Pesticide Board Subcommittee. Massachusetts Pesticide Bureau, Department of Food and Agriculture. 37 pp.

Borden, A. D.; H. F. Madsen and A.H. Retan (1952). A stink bug Euschistus conspersus, destructive to deciduous fruits in California. J. Econ. Ento. 45: 254-7.

Finney, D. J. (1971). Probit analysis, Cambridge Univ. press, London. 333p.

Hopkins, B. W. (2005). Species Composition and Seasonal Abundance of Stink Bugs in Cotton in the Lower Texas Gulf Coast and the Virulence of Euschistus sp. to Cotton. M.Sc. thesis, Texas A\&M University.

Khattak M. Khan; Sh. Ali; J. I. Chishti, A. R. Saljiki and Agha Shah Hussain (2004). Efficacy of certain insecticides against some sucking insect pests of mungbean (Vigna radiata L.). Pak. Entomol. 26 (1).

Maienfisch, P.; H. Huerlimann; A. Rindlisbacher; G. Laurenz, H. Dettwiler; J. Haettenschwiler; E. Sieger, and M. Walti (2001). The discovery of thiamethoxam: a second generation neonicotinoid. Pest Manage. Sci. 57: 165-176. (Cited by Tillman and Mullinix, 2004)

Muhammed, S. H., (1994). Study of population density of some sap sucking insects on some fruit trees in Erbil. M.Sc. thesis, College of Education, Univesrity of Salahaddin, Erbil, Iraq.

Nica, D.; E. Bainu and G. Chioveanu (2004). A case of acute intoxication with deltamethrin in Bee colonies in Romania. Apiacta 39:71-77.

NAR. (2001). Evaluation of the new active thiamethoxan in the product cruiser 350 FS insecticide seed treatment. National Registration Authority for Agricultural and Veterinary Chemicals, Po. Box E240, Kingston, Act 2604, Australia.

PeenState (2006). Plant bugs and stink bugs. Fruit production for the home gardner. College of Agricultural Science. Extension publications. Pennsylvania state, USA.

Schuh, R. T. and J. A. Slater (1995). True Bugs of the World. Cornell University Press. Ithaca, New York. 336 p. 